\title{
Masyarakat Nelayan Kampung Sicini Arungkeke, Jeneponto 2014-2017
}

\author{
Karmilawati, Najamuddin, M. Rasyid Ridha \\ Prodi Pendidikan Sejarah Fakultas Ilmu Sosial Universitas Negeri Makassar \\ karmilawati27@yahoo.com
}

\begin{abstract}
Abstrak
Penelitian ini bertujuan untuk mengetahui latar belakang masyarakat nelayan, munculnya modernisasi dan perkembangan alat tangkap serta bagaimana dampak yang ditimbulkan dalam kehidupan baik dalam bidang sosial, bidang ekonomi maupun dalam bidang pendidikan bagi masyarakat nelayan yang ada di Kampung Sicini. Hasil penelitian menunjukkan bahwa masyarakat nelayan yang ada di kampung Sicini kabupaten Jeneponto banyak menggantungkan hidupnya bekerja sebagai pelaut hal ini disebabkan karena wilayah lautnya yang sangat luas. Perkembangan kehidupan sosial ekonomi masyarakat di Kampung Sicini di mulai pada awal tahun 2014 yakni dengan masuknya motornisasi perahu yang dikenal dengan perahu Fiber. Perkembangan tersebut tidak terlepas dari peran pemeritah dimana diadakannya penyuluhan yang dilakukan oleh Dapertemen Kelautan dan Perikanan yang bekerja sama dengan pemerintah setempat tentang penggunaan teknologi modern. Berdasarkan hasil penelitian dapat disimpulkan bahwa masuknya teknologi modernisasi berupa penerapan teknologi modern dibidang perikan dapat menambah pendapatan masyarakat sekaligus meningkatkan taraf kehidupan sosial ekonomi masyarakatnya. Serta letak geografis kampung Sicini yang mendukung sumber daya laut untuk kehidupan nelayannya. Prosedur dalam penelitian ini menggunakan metode sejarah dengan tahapan: Heuristik, Kritik, Interpretasi dan Historiografi.
\end{abstract}

\section{Kata Kunci : Masyarakat Nelayan, Kampung Sicini, Jeneponto}

\begin{abstract}
Abstrack
This study aims to determine the background of the fishing community, the emergence of modernization and the development of fishing gear and how the impacts caused in life both in the social, economic and educational fields for the fishing community in Kampung Sicini. The results showed that the fishing communities in the Sicini village of Jeneponto district relied a lot on their lives working as sailors because of the vast sea area. The development of the socioeconomic life of the people in Kampung Sicini began in early 2014 with the introduction of boat motorization known as Fiber boat. This development is inseparable from the role of the government where counseling is held by the Ministry of Maritime Affairs and Fisheries in collaboration with local governments on the use of modern technology. Based on the results of the study it can be concluded that the inclusion of modernization technology in the form of the application of modern technology in fisheries can increase people's income while increasing the socio-economic standard of life of their people. As well as the geographical location of the Sicini village which supports marine resources for the lives of its fishermen. The procedure in this study uses the historical method with stages: Heuristics, Criticism, Interpretation and Historiography.
\end{abstract}

\section{Keywords: Fishermen Community, Sicini Village, Jeneponto}




\section{A. Pendahuluan}

Pada hakikatnya manusia, alam dan lingkungan merupakan suatu sistem yang saling berhubungan satu sama lain. Sebagai perwujudan dari adanya hubungan ini berupa interaksi-interaksi dan interpendensi. Sejak zaman dahulu manusia selalu berusaha untuk memenuhi kebutuhan hidupnya. Alam dan lingkungan diperlukan oleh manusia untuk melangsungkan kehidupannya. Adapun cara-cara pemenuhan kebutuhan manusia yang satu dengan manusia yang lainnya berbeda-beda sesuai dengan lingkungan masing-masing.Alam menawarkan berbagai sumber daya yang dapat diolah dan di manfaatkan untuk kepentingan manusia.

Secara geografis Indonesia merupakan negara laut terbesar di dunia. Luas wilayah lautnya 3,1 juta $\mathrm{Km}^{2}$, dengan panjang garis pantai $81.000 \mathrm{Km}$. di tengah laut tersebut ditaburi 17.508 pulau besar dan kecil (Hamid, AR. 2015). Salah satu karakteristik laut (dengan segala potensi ekonomi yang dikandungnya) dimana- mana dari dahulu hingga sekarang, ialah bahwa laut memiliki kekayaan bersama umat manusia common property. Bagi siapa saja yang menguasai faktor- faktor produksi (modal, teknologi, tenaga kerja keterampilan dan pengetahuan managerial yang tinggi) merekalah yang mempunyai akses memanfaatkan kekayaan laut semaksimal mungkin. Akibat dari karakteristik laut seperti itu ialah terjadinya persaingan dan konflik antara para pengelolah sumber daya laut yang menjurus pada munculnya kelas kaya dan miskin pada masyrakat nelayan; merosotnya persediaan sumber daya biotik laut; terjadinya kerusakan ekologi laut (Lampe, dkk., 1996).

Sulawesi Selatan termasuk salah satu wilayah Indonesia yang memiliki perairan yang cukup besar sehingga Potensi ini di manfaatkan sebagian besar masyarakatnya untuk menjadikan nelayan sebagai mata pencaharian pokok, maupun hanya sebagai sampingan dari mata pencaharian lainnya.
Di Indonesia, nelayan Bugis dan Makassar dikenal sebagai masyarakat bahari yang ulung, baik dalam sektor pelayaran (kemaritiman) maupun dalam sektor perikanan dan penangkpan ikan. Dalam sektorperikanan, nelayan Bugis dan Makassar telah menunjukkan fenomena perkembangan yang cukup progrestif, terutama dilihat pada proses perkembangan usaha dan teknologi penangkapan ikan (Lampe, dkk. 1996)

Terdapat sekurang-kurangnya enam jenis usaha perikanan berdarkan tipe teknologi penangkapan yang tetap dipertahankan dan dikembangkan oleh nelayan Bugis dan Makassar di Sulawesi selatan dan tempat-tempat lain di Indonesia. Keenam jenis usaha tersebut adalah bagang, rumpon, pakkaja (menangkapa ikan terbang), mencari teripang, memancing tongkol dan kerapu dikawasan taka (terumbu karang). Usaha perikanan dengan tipe-tipe teknologi tersebut dapat dikatakan sebagai andalan komoditas nelayan Sulawesi Selatan hingga dewasa ini (Lampe, dkk 1996).

Secara historis istilah nelayan pada awalnya memang hanya digunakan untuk menyebut orang yang menekuni pekerjaan menangkap ikan dilaut, yang secara sosiologis disebut defenisi tradisional. Hal ini disebabkan karena dalam pekerjaan ini, masih bersifat seragam antara satu dengan yang lainnya tanpa adanya semacam deferensiasi sosial (Lampe, dkk., 1996). yang melakukan pekerjaan seperti membuat jaring, mengangkut alat-alat penangkapan ikan kedalam perahu atau kapal motor, tidak dikategorikan sebagai nelayan.

Sesungguhnya nelayan bukanlah etnis tunggal mereka terdiri dari berbagai kelompok dibedakan menjadi tiga kelompok, yaitu nelayan buruh, nelayan juragan dan nelayan perorangan. Nelayan buruh adalah nelayan yang bekerja dengan alat tangkap milik orang lain. Sebaliknya nelayan jurangan adalah nelayan yang memiliki alat tangkap yang dioperasikan oleh orang lain. Adapun nelayan 
perorangan adalah nelayan yang memiliki peralatan tangkap sendiri dan dalam pengoperasiannya tidak melibatkan orang lain.

Berdasarkan teknologi peralatan tangkap ikan, nelayan dapat dibedakan menjadi nelayan tradisional dan nelayan modern. Nelayan modern lebih cenderung menggunakan teknologi canggih dan berpendapatan lebih besar dibandingkan nelayan tradisional, ini dikarenakan nelayan modern wilayah produksinya dapat menjangkau perairan yang lebih jauh (Rifal, 2017; Rifal \& Sunarti, 2018)

Karakteristik masyarakat nelayan berbeda dengan karakteristik masyarakat petani karena perbedaan sumberdaya yang dimiliki. Masyarakat petani (agraris) memiliki ciri sumberdaya yang lebih pasti dan visible sehingga relatif muda untuk diprediksi terkait ekspetasi sosial ekonomi masyarakat.sedangkan masyrakat nelayan akrab dengan ketidakpastian yang tinggi karena secara alamiah sumberdaya perikanan bersifat invisible sehinggga sulit untuk diprediksi. (Radyowirono, 2018).

Masyarakat nelayan secara umum termasuk dalam kategori masyarakat miskin yang berada pada level paling bawah yang paling sering mengalami penderitaan sebagai akibat dari ketidakberdayaan dan kerentanannya. Berbagai kajian yang telah dilakukan menemukan bahwa para nelayan (tradisonal) bukan saja harus berhadapan dengan ketidak pastian pendapatan dan tekanan musim paceklik ikan yang panjang, tetapi lebih dari itu mereka juga sering harus berhadapan dengan berbagai tekanan dan bentuk eksploitasi yang muncul bersamaan dengan berkembangnya proses modernisasi di sektor perikanan (Suyanto, dkk., 2005).

Masyarakat nelayan dapat diartikan sebagai orang atau manusia yang hidup bersama dalam waktu yang relatif lama, yang sadar bahwa mereka adalah satu kesatuan dan mempunyai pekerjaan atau mata pencaharian pokok menangkap ikan serta hasil laut lainnya (Ahmadin, 2009; Rezky Sani, Ahmadin, \& Amirullah, 2018)
Profesi sebagai nelayan yang dijalani oleh masyarakat di Kampung Sicini Desa Arungkeke diterima sebagai warisan dari generasi sebelumnya sehingga pola penangkapan ikan yang mereka lakukan tidak lepas dari tradisi yang telah dijalani oleh pendahulunya.

Hubungan antar individu dapat menjadi modal sosial yang menjadi sumberdaya yang berguna bagi individu itu sendiri yang melibatkan harapan dengan tujuan menjalin hubungan yang harmonis, erat, serta memiliki tingkat kepedulian antar sesama yang tinggi.

Masyarakat nelayan umumnya tinggal di daerah sepanjang garis pantai dan rumah nelayan di Kampung Sicini adalah rumah panggung yang merupakan ciri khas rumah panggung Bugis-Makassar. Kehidupan sosial ekonomi masyarakat nelayan di Kampung Sicini secara berangsur-angsur mengalami perubahan dimana teknologi penangkapan ikan khususnya motorisasi perahu sudah diterapkan.Modernisasi tersebut tentunya secara langsung membawa perubahan maupun pengaruh baik terhadap daya produksi maupun jarak tempuh.

Kampung Sicini berada di desa Arungkeke Kecamatan Arungkeke Kabupaten Jeneponto, Sulawesi selatan. Kampung ini didirikan pada tahun 2004 dan diresmikan 2010 oleh bapak Agung Laksono (Menkokestra). Kampung ini didirikan pada masa pemerintahan Bapak Drs. H.Radjramilo, MP (Bupati Jeneponto 2003-2013) (Wawancara dengan Kr. Kera).

Aktivitas kesehariannya merupakan fenomena tersendiri yang menarik untuk dijadikan obyek penelitian, karena aspek sosial ekonomi daerah ini cukup konplek untuk ditelaah secata ilmiah.

\section{B. Metode Penelitian}

Dalam penulisan suatu karya, terdapat cara yang digunakan dalam penyusunannya. Ini sering disebut dengan metode. Metode berasal dari kata Methodos (Bahasa Yunani) yang artinya acara atau jalan. 
Penelitian ini diarahkan untuk mengungkap serta menjelaskan latar belakang kehidupan sosial dan pola pemukiman masyarkat nelayan di Kampung Sicini Desa Arungkeke sehingga jelas diarahkan kepada metode penelitian sejarah yang bersifat kualitatif.

Dalam penulisan suatu karya ilmiah dipergunakan metode penulisan yang sesuai dengan kaidah penulisan sejarah yang sufatnya unik, dikatakan unik karena mempunyai metodologi penulisan sejarah melalui empat tahap kerja yaitu Heuristik (pengumpulan sumber), kritik sumber (eksternal/bahan dan internal/isi), Interpretasi (penafsiran) dan Historiografi (penulisan sejarah) (Saleh Majid, 2008).

1. Heuristik

Heuristik adalah teknik atau cara untuk mengupulkan sumber sejarah yang terkait dengan topik penelitian. Peneniliti menggumpulkan informasi mengenai masyarakat nealayan di Kampung Sicini Desa Arungkeke menempuh dua cara yaitu penelitian pustaka dan penelitian lapangan:

a. Penelitian pustaka

Studi pustaka merupakan salah satu langkah penting dalam penelitian sejarah. Dalam studi pustaka ini akan dilakukan studi terhadap sejumlah bahan pustaka, baik yang berupa arsip, buku, dan hasil penelitian lainnya yang memiliki kaitan dengan topik penelitian.

b. Penelitian Lapangan

Kegiatan yang dilakukan dalam penelitian lapangan adalah mengumpulkan sumber secara langsung terhadap objek yang menjadi sasaran penelitian.Dalam hal ini peneliti melakukan penelitian di Kampung sicin Desa Arungkeke Kecamatan Arungkeke Kabupaten Jeneponto.Peneliti mengunakan metode observasi dan metode wawancara. Kegiatan tersebut dijelaskan sebagai berikut:

1) Observasi

Observasi adalah pengamatan secara langsung terhadap objek yang diteliti atau terhadap lokasi penelitian.Pengamatan secara langsung terhadap masyarakat atau objek penelitian itu sendiri Kabupaten Jeneponto yang terkait dengan kehidupan nelayan.

2) Wawancara

Wawancara adalah proses komunikasi interaksi antara dua pihak yang setidaknya satu diantara mereka memiliki tujuan serius yang telah ditetapkan dan melibatkan proses Tanya jawab tentang sesuatu (Priyadi, 2017).

Peneliti melakukan wawancara terhadap orang yang dianggap berkompoten dalam objek yang diteliti.Peneliti melakukan wawancara terhadap Aparat desa, warga yang berprofesi sebagai nelayan dan pembuat perahu.. Adapun daftar informan yang peneliti wawancarai ialah Bapak $\mathrm{Kr}$. Jaling (sekretaris desa Arungkeke),Ibu Kr. Kera (kader Kampung sicini/Aparat Desa), Bapak kamiseng, bapak muhaming, (nelayan/petani garam) serta Bapak Saruddin (pembuat perahu). Dari wawancara yang dilakukan peneliti terdapat beberapa hal yang dapt diketahui seperti awal mula masyarakat nelayan di Kampung Sicini, perkembangan alat tangkap serta dampak kehidupan sosial ekonomi masyarakat nelayan yang ada di Kampung Sicini tersebut.

2. Kritik

Jika sumber-sumber yang digunakan sudah dianggap cukup langkah selanjutnya adalah melakukan kritik terhadap sumber yang telah didapatkan.Dalam kritik sumber, terdapat penekanan tertentu yang bertujuan untuk memberikan defenisi kritik sumber itu sendiri. Adapun hasil dari tahapan kritik ini yakni diperoleh fakta-fakta sejarah ( Helius Sjamsuddin. 2012).

Sehingga karya sejarah yang dihasilkan merupakan produk dari proses ilmiah yang dapat di pertanggung jawabkan bukan hasil dari suatu fantasi maupun manipulasi guna untuk menentukan otensitas (keaslian sumber) dan kredibilitas (tingkat kebenaran informasi) sumber sejarah.

3. Interpretasi

Interpretasi adalah proses pemaknaan makna sejarah. Interpretasi diperlukan agar 
data yang mati bisa bicara atau mempunyai arti. Fakta-fakta sejarah harus di interpretasikan atau ditafsirkan agar suatu peristiwa dapat dikontruksikan dengan baik, yakni dengan jalan menyeleksi, menyusun, mengurangi tekanan, dan menempatkan fakta dalam urutan kasual (Alian).

Dalam tahap ini penulis dituntut untuk bisa menghasilkan interpretasi yang tidak memihak dan sesuai dengan kebenaran fakta yang ada karena unsur subjektivitas terkadang dapat mempengaruhi isi penulisan.Hal ini dimaksud untuk memberi arti terhadap aspek yang diteliti, mengaitkan fakta lainnya agar ditemukan kesimpulan penulisan ilmiah.

\section{Historiografi}

Historiografi adalah penulisan hasil penelitian.Tahap ini merupakan tahap akhir dalam penelitian sejarah. Pada tahapan ini peneliti akan menuliskan peristiwa sejarah tersebut dalam sebuah tulisan yang dalam penulisan, pemaparan dan pelaporan menggunakan tatacara tertentu. Dimana dalam hal ini, penelitian yang penulis lakukan adalah penelitian dengan kajian kepustakaan dan lapangan. Penulisan sejarah merupakan proses penjelasan dari semua kegiatan dalam proses penelitian sejarah. Pada tahap ini penulisan hasil penelitian sejarah seharusnya dapat memberikan gambarang yang jelas mengenai proses penelitian dari awal sampai akhir

\section{Tinjauan Lokasi Penelitian \\ 1. Keadaan Geografis}

Kabupaten Jeneponto secara geografis terletak di 5 $5^{\underline{0} 23-5^{\circ}}$ 42 Lintan Selatan dan 119²9 Bujur Timur kabupaten ini berjarak $91 \mathrm{Km}$ dari Makassar. Berbatasan dengan Kabupaten Gowa dan Takalar di sebelah utara, Kabupaten Bantaeng di sebalah timur, Kabupaten Takalar sebelah Barat dan Laut Flores Sebelah Selatan. Luas Wilayah Kabupaten Jeneponto adalah $749,79 \mathrm{Km}^{2}$ dan terdiri dari 11 Kecamatan. Ada 342.700 Jiwa (85.676 keluarga) yang tinggal di Kabupaten Jeneponto. Dengan Kecamatan Bangkala Barat sebagai kecamatan paling luas yaitu 152,96 $\mathrm{Km}^{2}$ atau setara 20,4 persen Kabupaten Jeneponto. Adapun kecamatan tercekil adalah Arungkeke yakni seluas 29,91 $\mathrm{Km}^{2}$ (Jeneponto, 2013).

Kecamatan Arungkeke adalah salah satu kecamatan yang berada di Kabupaten Jeneponto dimana Desa Arungkeke termasuk dalam wilayahnya. Secara geoagrafis Desa Arungkeke mempunyai batasan wilayah Desa Arpal sebelah Selatan, Desa Borong Lamu sebelah Utara, Desa Palajau sebelah Timur dan Sebelah Barat Desa Bulo-bulo. Luas wilayah Desa Arungkeke kurang lebih $3,9 \mathbf{K m}^{2}$ yang terdiri atas yaitu :
a. Dusun Pallengu
b. Dusun Tamanroya
c. Dusun Petang
d. Dusun Punagaiya
e. Dusun Lassang-lassang

Kampung Sicini merupakan salah satu daerah yang termasuk administratif masuk ke wilayah Dusun Punagaiya Desa Arungkeke kecamatan Arungkeke. Kampung Sicini berjarak $1 \mathrm{Km}$ dari dusun Punagaiya dengan batas-batas wilayah sebagai berikut :

1. Sebelah Utara: Laut Flores

2. Sebelah Selatan: Tamanroya

3. Sebelah Barat: Dusun borong lamu

4. Sebelah timur: Dusun Petang

Dengan luas wilayah \pm 20 Ha. Keadaan alam kampung Sicini termasuk daerah pesisir pantai dengan hasil utamanya dari sektor hasil laut. Karena sebagian besar penduduknya bermata pencaharian sebagai nelayan dan petani rumput laut. Pusat pemerintahan berada di dusun Pallengu yang terletak di jalan provinsi yang jaraknya dari ibu kota Kabupaten Jeneponto $\pm 11 \mathrm{Km}$ arah Barat.

Untuk mencapai daerah ini kita cukup menggunakan alat transportasi darat yaitu mobil atau kendaraan bermotor yang dapat ditempuh dalam waktu dua sampai 
tiga jam dari kota Makassar dan kurang lebih 20 menit dari pemerintahan Kabupaten (Jeneponto).

2. Gambaran umum demogratif

Penduduk merupakan potensi yang terpenting karena pelaksanaan pembangunan juga sebagai objek pembangunan itu sendiri atau dengan kata lain faktor penduduk itu pentingterutama dalam kaitannya dengan peningkatan taraf hidup mereka. (Khadijah 2013). terutama pada nelayan khususnya nelayan di Kampung Sicini. Berdasarkan Data Administratif pemerintah, jumlah penduduk yang tercatat dalam secara administrasi pada bulan juli tahun 2016 jumlah total penduduk 299 jiwa. Dengan rincian penduduk berjenis kelamin laki-laki berjumlah 117 jiwa, sedangkan berjenis kelamin perempuan berjumlah 182 jiwa. (Arsip kantor Desa Arungkeke).

3. Keadaan Sosial Ekonomi

Masyarakat nelayan adalah masyarakat yang hidup tumbuh dan berkembang di kawasan pesisir. Masyarakat nelayan adalah masyarakat dengan mata pencaharian yang hasil tangkapan melimpah. Masyarakat nelayan memiliki karakteristik sosial yang membuat suatu kesatuan sosial.

Nelayan bukanlah etnis tunggal mereka terdiri dari berbagai kelompok dibedakan menjadi 5 kelompok, yakni: 1) Nelayan pemilik (jurangan). 2) Nelayan Penggarap. 3) Nelayan Tradisional. 4) nelayan Kecil. 5) Nelayan Gendong. (dalam Endang Retnowati 2011).

Ekonomi merupakan bagian yang sangat berpengaruh bagi pertumbuhan suatu wilayah oleh karena itu disetiap sumber daya alam potensial dan dikaregorikan sebagai unggulan perlu dikembangkan lebih lanjut dalam sentrasentra produksi. Adapun unggulan yang potensi dapat dikembangkan di kampung sicini dan menjadi modal dasar pertumbuhan adalah perdagangan dan perikanan laut.

\section{Pembahasan}

1. Latar Belakang Modernisasi
Usaha pemotoran (motornisasi) dan pemesinan alat tangkap (mekanisasi) perlengkapan ikan di Indonesia pada umumnya mulai diterapkan sejak tahun 1970-an. Langkah selanjutnya adalah upaya pembangunan sarana panjang penangkapan,seperti pembanguna pelabuhan perikanan dan tempat pelelangan ikan (TPI) yang dilengkapi oleh fasilitas pendukung meliputi air bersih,es, bengkel, dan infrastruktur lainnya pada beberapa desa nelayan yang menjadi sentral produksiperikanan (Ahmadin. 2009).

Modernisasi mencakup transformasi sistem, yang memungkinkan manusia mengorganisasikan masyarakatnya (atau perubahan sistem). Proses modernisasi menciptakan profesi baru, yang mengakitbatkan perubahan mendasar pada pola kerja atau perubahan fungsional. Modernisasi pada masyarakat juga diartikan sebagai pergantianteknik produksi dari cara-cara tradisional ke cara-cara modern.Meskipun demikian. Proses itu tetap merupakan sebuah gejala sosial.(Ahmadin 2009).

Di samping itu nelayan sebagai pihak yang menggunakan teknologi sebagai bagian dari modernisasi tersebut dihadapkan pada suatu pilihan untuk mengadopsi atau tidak teknologi tersebut. Berbagai faktor yang mempengaruhi adopsi tersebut antara lain adalah bagaimana nelayan tersebut memaknai laut serta pekerjaan nelayan yang digeluti selama ini. Pemaknaan tersebut sangat penting oleh karena itu mencakup cara pandang mereka terhadap sesuatu/objek yang berkaitan langsung dengan mata pencaharian mereka pada berbagai aspek yakni aspek ekonomi, sosial (sosiologis) religius (teologis), psikologis serta budaya. (Awaluddin Hamza 2009).

Melalui modernisasi perahu nelayan yang ada di Kampung sicini secara umum berhasil meningkatkan produksi.dimana motornisasi perahu untuk mendukung kegiatan nelayan merupakan manifestasi dan strategi adaptasi nelayan di Kampung Sicini dalam merespon perkembangan modernisasi perikanan. Modernisasi yang 
dimaksud disini adalah penggunaan perahu fiber sebagai tenaga penggerak. Semua nelayan mendambakan memiliki perahu motor atau perahu fiber.

Masuknya teknologi dalam hal ini modernisasi perahu dikampung Sicini didukung oleh beberapa faktor salah satunya adalah pemerintah dimana Modernisasi pertama kali dikenalkan kepada masyarakat nelayan di Kampung Sicini yaitu pada tahun 2014 dimana diadakannya penyuluhan yang dilakukan oleh dapertmen kelautan dan perikanan yang bekerja sama dengan pemerintah setempat tentang penggunaan teknologi modern.

Sebelumnya masuknya modernisasi di Kampung Sicini pada awal tahun 2000an masyarakat nelayan masih menggunakan perahu tradisional seperti Sombala' ataupun lepa-lepa yang digunakan untuk melaut dengan jarak tempuh yang terbatas karena masih menggunakan tenaga manusia dan bantuan tenaga angin. Setelah masuknya modernisasi perahu pada tahun 20014 di kampung Sicini nelayan telah menggunakan perahu yang sudah digerakkan dengan mesin dan jangkauaan perjalanannya jauh yang masyarakat setempat menyebut perahu fiber. Kayu yang dibuat untuk perahu fiber menggunakan kayu sirian (Pala'-pala') yang berasal dari tanete, membuat perahu juga tidak boleh menggunakan kayu sembarang kita harus emilih kayu yang tahan air. Perahu ini di kisar dari Rp 6.000.000 8.000.000. Ukurannya pun berbeda-beda mulai dari 8-10 meter. perahu ini dibuat di lassang-lassang.

Teknik penangkapan ikan dengankail secara individual menggunakan sampan sebagai aramada. Daya jangkau operasi melalui penggunaan teknolgi tangkap seperti ini berkisar di tepi pantai. Sebuah sampan untuk aktivitas memancing umumnya diawaki 1-2 orang nelayan rendahnya tingkat pendidikan nelayan mengakibatkan kurangnya keterampilan.

Kegiatan menangkap ikan menggunakan Jala (jaring) merupakan aktifitas penangkapan ikan dengan menggunakan teknolgi jaring tradisional yang digerakkan tenaga manusia. Jenis jenis ikan tertangkap umumnya ikan yang mempunyai harga jual tinggi seperti ikan lori, sunu, mosso, pari dan cakalang. Oleh sebab itu kegiatan mencari ikan di laut sebagi nelayan tersebut dapat meningkatkan pendapatan nelayan itu sendiri. Salah satu jenis ikan yang paling ekonomis yang dapat ditangkap sepanjang tahun yakni ikan cakalang.

Di Kampung Sicini terdapat usaha penangkapan ikan yang masih tradisional yang dikelolah dengan skala ekonomi rendah dan manajemen usaha yang bersifat keluarga.Jenis alat tangkap yang di gunakan yaitu pancing, jaring, maupun rawi'. Pada alat tanggakap ini tidak terdapat suatu organisasi kerja karna biasanya proses penangkapan dilakukan secara sendirisendiri.

Modal awal mula-mula nelayan di kampung Sicini sebelum berangkat melaut semuanya di peroleh dari hasil pinjaman dari bos ikan. Adapun biasanya modal awal yang dibawah sebelm melaut itu bervariasi kirasan antara Rp. 100.000300.000 sekali melaut tergantung kebutuhan para nelayan. Berbeda lagi ketika melaut pada hari-hari berikutnya biasanya nelayan menggunakan modal sendiri.

Pembagian hasil tangkapan sesuai dengan ikan yang ada di jaring atau pancing masing-masing nelayan. Jadi tidak ada sistem bagai hasil .karena setiap nelayan membawa peratan sendiri-sendiri termasuk umpan yang digunkan, sedangkan uang yang bawa sebagai modal tranportasi mereka melaut. Nelayan kecil biasanya melaut menggunakan perahu milik masingmasing yang diawaki 1-2 orang.

Masyarakat nelayan yang ada di Kampung Sicini tidak mengunakan sistem bagi hasil karena pendapatan para nelayan tidak menentu setiap harinya. Dimana hari ini nelayan mendapatkan hasil tangkapan yang banyak kemudian di hari berikutnya 
tidak mendapatkan hasil tangkapan atau hanya cukup untuk makan sehari.

Wawancara dengan bapak dadi (34 tahun) yang mengunakan perahu orangtua untuk melaut responden mengatakan:

"Tidak ada sistem bagi hasil yang saya lakukan dengan orangtua saya kalupun penghasilan saya banyak setelah pulang melaut ya kita kasi juga sediki tapi kalau tidak banyak kita tidak kasi cukup di pake untuk keperluan sehari-hari.” (wawancara Bapak Dadi).

Berbeda dengan responden Bapak Wawancara dengan responden bapak Sainuddin (53 tahun), bapak Kamiseng (57 tahun) terkait dimana hasil tangkapannya di jual ia mengatakan:

"Niat tau battu mae ngallei tata'. Niang tong kamma punggawa angngongkosiki, punna battu mae na nia' ni gappa ia ngallei, mange balukangi, jari punna la lampamaki ammekang mangeki pala ongkoso, ri paballi pekang, kaluru sagala-galana. Ia angngongkosi."

Artinyanya: ada orang tetap yang datang, ada yang disebut sebagai punggawa (bos ikan) yang membiayai, kalau misalkan dia (punggawa) datang kemudian ada hasil tangkapan nelayan punggawa yang ambil lalu menjualnya kepada konsumen. Jadi ketika kita ingin berangkat melaut maka mengambil modal kepada bos. Segalagalanya bos yang membiayai baik itu pancing, rokok maupun Bahan Bakar Minyak (BBM).

Ketika nelayan menggunakan modal sendiri maka hasil tangkapannya bisa langsung di jual kepada konsumen yang datang ke Kampung Sicini untuk membeli ikan yang segar langsung dari nelayan tersebut. Transaksi jual beli diadakan didarat dengan mengunakan metode tawar menawar antar nelayan dan konsumen untuk mendapatkan kesepakatan harga jual beli.
Wawancara dengan Bapak Mangga' (52 tahun) responden mengatakan:

"Nia tonja iyya sipaangang ia buru'nenna lampa mange boya juku, battu mae bainenna mange ambalukangi nia tonja kanne mae joka ni rekengan tanre punggawana/bosna”

Artinyanya: ada juga pasangan suami istri dia suaminya pergi melaut menangkap ikan kemudian setelah pulang dari melaut barulah istrinya yang pasarkan ada juga yang begitu disini mereka terhitung dalam tidak memiliki.

Setelah masuknya modernisasi di kampung sicini pada tahun 2014, maka nelayan mulai melepaskan diri dari pemilik modal dan mulai mengusahakan modal sendiri seperti misalnya bapak Suriadi ketika tidak berangkat melaut maka beliau melakukankan pekerjaan sebagai buruh bangunan yang hasil kerjanya di tabung kemudian di putar kembali sebagai modal untuk melaut nantinya.

2. Dampak Terhadap Kehidupan Masyarkat Nelayan Di Kampung Sicin Perkembangan modernisasi

Khususnya motornisasi perahu nelayan mengakibatkan daya operasional penangkapan ikan mengalami peningkatan. Sebelum adanya penggunaan mesin, waktu tempuh nelayan menuju lokasi penangkapan ikan bisa memakan waktu berjam-jam, berhari-hari lamanya bahkan bisa sampai sebulan lama perjalanan, bergantung lokasi penangkapannya. Adanya modernisasi ini tentunya sangat menguntungkan Jika ditelusuri sejarahnya, perkembangan dari segi alat tangkap maka dapat ditemukan pengaruh baik dalam bidang sosial, ekonomi ataupun pendidikan masyarakat. Untuk lebih jelasnya dapat di kemukakan sebagi berikut:

a. Dampak Dalam Bidang Sosial

Modernisasi perikanan berdampak pada kehidupan sosial nelayan dan komunitas nelayan lainnya. Dampak tersebut adalah perubahan pola kerja dari penggunaan teknologi lama yang masih 
sederhana menjadi teknologi baru yang lebih modern, efektif dan efisien. Efektivitas dan efisiensi modernisasi tersebut menimbulkan deferensiasi yakni munculnya unit-unit baru yang berdampak pada perubahan struktur sosial nelayan. Perubahan struktur tersebut terjadi pada level nelayan maupun komunitas.

Masyarakat nelayan memiliki struktur sosial yaitu patron-klien. Patron-klien mempunyai implikasi bahwa orang yang masih terhitung kerabat tidak masuk didalamnya atau orang yang saling tolongmenolong dan masih terdapat hubungan kekerabatan antar mereka tidak tercakup di situ.James Scott (Arif 2015) Stratifikasi atau strata sosial suatu masyarakat pada hakikatnya dipahami sebagai latar belakang pandangan hidup, waktu, sifat-sifat mendasar bahkan merupakan warna dan corak dari hubungan-hubungannya.

(Ahmadin. 2009). Stratifikasi sosial masyarakat jeneponto pada umumnya dan di Kampung Sicini pada khususnya sama dengan sistem pelapisan sosial masyrakat Bugis-Makassar. Ada tiga lapisan yaitu Anak Karaeng, Tomaradeka (Daeng), dan Ata.

Dari hasil penelitian yang dilakukan di Kampung Sicini ini diketahui bahwa kehidupan sosial masyarakat masih sangat kental dimana hubungan kekeluargaan mereka begitu sangat erat. Hal ini muncul ketika seorang nelayan mengalami musibah misalnya, bahan bakarnya habis sehingga mengakibatkan nelayan tersebut pulang melaut tidak pada waktu yang biasanya.Mereka para nelayan bekerja sama untuk mencari rekan seprofesinya di laut tanpa dikomando oleh pemerintah setempat ataupun dari pihak manapun diluaran mereka.

Hubungan sosial masyarakat dengan masyarakat lainnya sebagai variasi hubungan serta berdampingan dengan prinsip kesukarelaan, kesamaan, kebebasan, dan keadaban. Norma-norma sosial akansangat berperan dalam mengontrol bentuk-bentuk perilaku yang tumbuh dalam masyarakat. Pengertian norma itu sendiri adalah sekumpulan aturan yang harus dipatuhi dan diikuti serta dijalankan oleh anggota masyarakat pada suatu kelompok sosial tertentu.

Norma-norma biasanya terinstitusionalisasi dan mengandung sanksi sosial yang dapat mencengah individu berbuat sesuatu yang menyimpang dari kebiasaan yang berlaku dalam masyarakatnya. Aturan-aturan kolektif tersebut biasanya tidak tertulis tapi dipahami oleh setiap anggota masyarakatnya dengan menentukan pola tingkah laku yang diharapkan dalam konteks hubungan sosial (Hasbullah, 2006).

b. Dampak dalam Bidang Ekonomi

Ada banyak perubahan yang telah terjadi pada masyarakat nelayan di Kampung Sicini yang disebabkan oleh kemajuan teknologi dan perkembangan pengetahuan masyarakat. Salah satu perkembangan yang dapat kita temui adalah dalam bidang ekonomi. Dalam hal peningkatan hasil tangkapan yang dicapai sehingga mampu meningkatkan pendapan nelayan.

Pra-modernisasi atau sebelum modernisasi (2000-an) masuk pada sektor perikanan, kondisi masyarakat nelayan di kampung Sicini masih jauh dari tingkat sejahtera. Kehidupan mereka sangat bergantung pada alam dan kondisi cuaca. Karena peralatan mereka yang masih sangat tradisonal yakni memaki perahu layar (sombala') dan alat tangkap ikan yang sederhana serta menguras banyak tenaga. Dengan demikian minimnya hasil tangkapan ikan sehingga perekonomian masyarakat masih sangat rendah.

Memasuki tahun 2015 kondisi masyarakat nelayan di kampung Sicini berangsur mulai mengalami perubahan yang signifikan. Mereka mulai mengenal adanya modernisasi perahu yang ditandai dengan penggunaan mesin pada perahu. Perubahan fisik yang terlihat pada kampung Sicini, rumah para nelayan kini telah mengalami perubahan secara perlahan dimana para nelayan sudah dapat 
merenovasi rumah mereka jauh lebih bagus.

Ketika arus laut tidak memungkinkan untuk nelayan melaut, maka nelayan bisa mengupayakan pekerjaan lain yakni buruh/tukang bagunan, petani garam, dan petani rumput laut. Maka dapat dikatakan bahwa ketika masyarakatnya sendiri yang betul-betul malas dan tidak mau mencari kehidupan yang lebih baik maka taraf hidupnya akan susah dan tidak dapat memanfaatkan sumber daya laut yang melimpah.(wawancara kr kera).Hal tersebut dapat menjelaskan bahwa kehidupan ekonomi di kampung Sicini mengalami perkembangan disebabkan adanya penambahan mata pencaharian sehingga pekerjaan tersebut tentunya sangat membantu penduduk dalam bidang ekonominya.

Perekonomian masyarakat dapat dipengaruhi oleh berbagai bidang, biasanya bidang tersebut berdasar pada peran atau aktivitas sehari-hari yang dilakukan oleh masyarakat. Hasil wawancara diatas dapat disimpulkan bahwa masyatarakat nelayan yang ada di Kampung Sicini sangat menyadari bahwa pendidikan itu penting. Pendidikan juga bisa mengangkat harkatdan martabat keluarga. Selain pendidikan formal masyarakat nelayan di Kampung Sicini menyadari bahwa pendidikan tidak mesti diperoleh dari bangku sekolah, melainkan bisa didapat dari keluarga maupun lingkungannya.

c. Dampak dalam bidang Pendidikan

Rendahnya pendidikan pada masyarakat nelayan di kampung Sicini maka mempengaruhi pekerjaan yang dimiliki oleh masyarakatnya karena dengan rendahnya berarti rendah pula kemampuan individual.Hal tersebut berpengaruh anggapan masyarakat lebih memilih pekerjaan yang mengandalkan tenaga saja.

Dengan hasil yang diperoleh dengan mata pencahariannya sebagai nelayan digunakan untuk memenuhi kebutuhan hidup sehari-sehari dengan hasil yang tidak pasti tersebut menyebabkan tidak terpenuhnya sebagian kebutuhan hidup termasuk salah satunya kebutuhan dalam bidang pendidikan.

Namun hasil wawacara peneliti,pada 2 tahun belakang ini masyarakat yang tinggal di wilayah pesisir kini menjadi prioritas utama dalam bidang pendidikan baik pendidikan formal maupun pendidikan keagaaman. Dimana pemerintah desa beranggapan bahwa masyarakat pesisir notabenenya berusaha tidak ada yang dianggap buta aksara (buta huruf). Hampir semua di Desa Arungkeke tercover dalam bidang pendidikan, sosial maupun ekonomi. Dilihat dari adanya sekolah Paud, TK maupun sekolah SD yang dibangun di wilayah kampung Sicini. Meskipun orang tuanya nelayan tetapi mereka peduli akan pendidikan anaknya. (Wawancara dengan bapak Abdurrakhman Abbas Kr. Jalling).

Pendidikan yang paling penting yaitu pendidikan dalam bidang keagamaan, dimana di Kampung Sicini telah dibentuk TK/TPA untuk mengajar anak-anak membaca dan menulis alquran dengan baik dan benar. Dalam 1 TK/TPA per-Dusun muridnya terdiri dari puluhan siswa, dan intensifnya guru TK/TPA dianggarkan di Desa sebagai bentuk ucapan terimakasih telah meluangkan waktunya untuk memberikan sedikit ilmunya kepada muridmurid ditengah aktivitas yang padatJadi betul-betul upaya pemerintah ke masyarakat dapat terlaksana dengan baik.TK/TPA itu sendiri di bentuk pada awal periode pemerintahan Bapak Drs. $\mathrm{H}$. Radjamilo, MP (Bupati Jeneponto 20032013). (Wawancara dengan bapak Abdurrakhman Abbas Kr. Jalling ). Memang ada yang namanya pengwisudaan TK/TPA kemudian di Sekolah sekarang ini dijadikan suatu persyaratan ketika melanjutkan pendidikan kejenjang yang lebih tinggi.

\section{E. Kesimpulan}

Latar belakang awal mula masyarakat nelayan di Kampung Sicini Desa Arungkeke Kemamatan Arungkeke Kabupaten Jeneponto berdasarkan pada 
letak geografis Desa Arungkeke terletak di sekitar pantai sehingga sebagian besar pendududuknya bermata pencaharian sebagai nelayan. Kampung Sicini didirikan pada tahun 2004 dan diresmikan pada tahun 2010 oleh bapak Agung Laksono Mentri Kesejahteraan Masyarakat (MENKOKESTRA). Kampung ini didirikan pada masa pemerintahan Bapak Drs. H.Radjamilo, MP (Bupati Jeneponto 2003-2013). Sebelum dibentuknya sebuah perkampungan yang saat ini di kenal dengan Kampung Sicini awalnya hanya sebuah tanah kosong namun jauh sebelum dibentuknya kampung sicini pada tahun 90an sudah ada beberapa nelayan yang tinggal dipesisir pantai.

Perkembangan alat tangkap dapat dilihat dengan adanya motornisasi perahu yang digunakan oleh nelayan di Kampung Sicini. Adanya motivasi dari nelayan untuk hidup yang lebih sejahterah sehingga di lakukan penyeluhan tidak lepas dari peranan pemerintah setempat. Modernisasi mulai diterapkan pada tahun 2014 .

Adapun dampak yang ditimbulkan setelah munculnya modernisasi baik dalam bidang sosial, ekonomi maupun pendidikan berangsur- angsur mengalami peningkatan sehingga meningkatkan taraf hidup masyarakat nelayan yang ada di Kampung Sicini.

\section{DAFTAR PUSTAKA}

Ahmadin. (2009). Ketika Lautku Tak Berikan Lagi. Makassar: Rayhan Intermedia.

Alamsyah, A. 2016. Solidaritas Sosial Masyarakat Nelayan dalam Penangkapan Ikan di Kelurahan Bentenge Kec. Ujung Bulu Kab. Bulukumba. Skripsi. Fakultas Ushuluddin Filsafat dan Politik. UIN Alauddin Makassar. Makassar.

Haerianty Rezki sani. 2018. Modernisasi Alat Tangkap Ikan Nelayan di Desa Panaikan Kec. Sinjai Timur Kab. Sinjai (1955-2017).
Hamid, AR. 2015. Sejarah Maritim Indonesia. Ombak. Yogyakarta.

Hamid, Pananrangi. Kehidupan Sosial Ekonomi Masyarkat Nelayan Tradisional Daerah Jeneponto (Laporan Survai). Balai Kajian Sejarah dan Nilai Tradisional Ujung Pandang. Makassar.

Jaya, Husni. 2003. Mengenal Kehidupan Pesisir dan Laut. Wilda Setiakarya.

Jeneponto, B. P. S. K. (2013). Jeneponto dalam Angka 2015. Jeneponto: BPS.

Khadijah. 2013. Studi Hubugan Kerja Masyarkat Nelayan Kelurahan Ponjalae, Kec. Wara Timut Kota Palopo. Skripsi. Fakultas Ilmu Sosial dan Ilmu Politik. Universitas Hasanuddin. Makassar.

Lampe, dkk. 1996. Sistem Penguasaan Wilayah Perikanan dan Pemanfaatan Sumber Daya Hayati Laut Oleh Masyrakat Nelayan Bugis Makassar di Sulawesi Selatan. Dapartemen Pendidikan dan Kebudayaan RI.

Mahmud, M. 2007. Rappang (1985-2000). Kehidupan Sosial Ekonomi Masyarkat Nelayan Di Kecamatan Pamboang Kabupaten Majene (19902005). Skripsi. Fakultas Ilmu Sosial. Universitas Negeri Makassar. Makassar.

Nurfadillah. 2016. Peran Masyarakat Nelayan Terhadap Peningkata Ekonomi di Desa Kenje Kec. Campalagian Kab. Polewali Mandar. Skripsi. Fakultas Ekonomi dan Bisnis Islam. Universitas Islam Negeri Alauddin Makassar. Makassar.

Ridasari dan Bachtiar. 2007. Budidaya Laut dan Teknologi Penangkapan Masyrakat Nelayan Pulau Sembilan Kabupaten Sinjai. Departemen Kebudayaan dan Periwisata Direktorat Jendral Nilai Budaya, Seni dan Film Balai Pelestarian Sejarah dan Nilai Tradisional.

Priyadi, S. (2017). Sejarah Lisan. Yogyakarta: Ombak.

Rezky Sani, H., Ahmadin, A., \& Amirullah, A. (2018). Penetrasi Nelayan 
Tradisional Panaikang 1955-1970. Jurnal Pattingalloang. https://doi.org/10.26858/pattingalloang .v5i1.6705

Rifal. (2017). Modernisasi dan Ekonomi Masyarakat Nelayan Kampung Gusung Kotamadya Ujung Pandang Tahun 1954-1998 (Universitas Indonesia). Retrieved from http://lib.ui.ac.id/detail?id=20455918\& lokasi=lokal

Rifal, P., \& Sunarti, L. (2018). The impact of modernization on the economy for fishermen in Makassar City. Cultural Dynamics in a Globalized World.

Suhartono, Pranoto. 2010. Teori dan Metodologi Sejarah. Graha Ilmu. Yogyakarta.

Syahma, A. 2016. Analisis Faktot- factor yang Mempengaruhi Pendapatan Nelayan Tangkap di Desa Galesong Kota Kec. Galesong Kab. Takalar. Skripsi. Program Studi Ilmu Ekonomi Pembangunan. Universitas Negeri Makassar. Makassar.

Tam, MI. 2003. Studi tentang Kehidupan Sosial Ekonomi Masyarakat Nelayan Danau Sidenreng di Desa Mojong Kabupaten Sidenreng. Skripsi. Fakultas Ilmu Sosial. Universitas Negeri Makassar. Makassar.

Tim Pengajar Jurusan Pendidikan Sejarah. 2014. Pengantar Ilmu Sejarah. Universitas Negeri Makassar. Makassar.

Zainal, Zulviah. 1997. Sistem Ekonomi Tradisional Masyarakat Nelayan Musiman di Pajukukan Kabupaten Maros. (Laporan Penelitian Sejarah dan Nilai Tradisional Sulawesi Selatan). Departemen Pendidikan dan Kebudayaan Direktorat Jendral Kebudayaan Balai Kajian Sejarah dan Nilai Tradisional Ujung Pandang. Makassar. 